\title{
Checklist of Herpetofauna in Sungai Mudal Park and Kembang Soka Waterfall
}

\author{
Ana Ghoyatul Qusway ${ }^{*}$ Itsnaini Fadhilah Sifa ${ }^{* *}$ \\ Biology Education Department, Faculty of Science and Technology, UIN Sunan Kalijaga \\ J1. Marsda Adi Sucipto No. 1 Yogyakarta 55281 Indonesia. Tel. +62-274-540971, Fax. +62-274-519739 \\ Email: anna.aghoy@gmail.com*, itsnasifa@gmail.com ${ }^{* *}$
}

\begin{abstract}
Herpetofauna in Indonesia is very abundant, one of the richest areas of herpetofauna in Indonesia is in the Menoreh Mountain of Kulon Progo. Girimulyo started pioneering the natural tourist in the Kembang Soka Waterfall and Sungai Mudal Park. In 2012 the diversity in this place was researched by Qurniawan et al. This study aimed for renewing data of herpetofauna. The study was conducted from February to June 2018. This study used VES (Visual Encounter Survey) method, which works in combination with the belt transect method. A total of 22 Herpetofauna species has been found and identified in the Sungai Mudal Park and Kembang Soka Waterfall consists of 9 families, 5 families from the Amphibian class and 4 families from the Reptile class.
\end{abstract}

Keywords: Checklist, Herpetofauna, Kembang soka waterfall, Sungai mudal park

\section{INTRODUCTION}

Herpetofauna comes from the word herpeton which means 'creeping animal'. Amphibians and reptiles included in the branch of zoology namely herpetology, as they have a way of life and habitat that almost similar and equal ectothermic vertebrate or animals that require external heat sources (Kusrini, 2007). Most herpetofauna can be found in tropical forests areas, swamps, and rivers. The presence of herpetofauna is dependent on the climate formed by the association between existing vegetation (Iskandar, 1998). Herpetofauna has an important role in maintaining the balance of food chain in the ecosystem both as predators or prey (Zug, 1993).

Herpetofauna in Indonesia is very abundant, the International Union for Conservation of Nature (IUCN) states that there are 1.500 species of Indonesian herpetofauna stored in the Bandung Zoological Museum (IUCN, 2013). One of the richest areas of herpetofauna in Indonesia is in the Menoreh Mountain of Kulon Progo. In this area, there were natural attractions the karst caves such as Kiskendo Cave and Seplawan Cave (Purworejo Regency). Last three years, Girimulyo community started pioneering the natural tourism namely the Kembang Soka Waterfall and Sungai Mudal Park. Instead, the alteration function of land become a tourist object is feared to have a negative impact on the Menoreh Mountain ecosystem. Herpetofauna as an animal that needs its environment in its body's metabolic process (ectothermic), it is very suitable to see this phenomenon because the new tourism object covers the waters which are the herpetofauna habitat, especially amphibians to breed (Qurniawan, 2013).

In 2012 diversity research was conducted by Qurniawan et al in Girimulyo. The study obtained data
40 types of herpetofauna with 7 families of reptile class and 6 families of amphibian class. The number of 40 herpetofauna species consists of 15 types of Anura orders, 15 types sub-orders of lacertilia and 10 other types sub-order of serpentes (Qurniawan et al., 2012).

\section{MATERIALS AND METHODS}

\section{Location and Date}

The study was conducted in February to June 2018. Total 14 data collection times with 7 data collection times in the Sungai Mudal Park and Kembang Soka Waterfall. Data collection was carried out in the Sungai Mudal Park and Kembang Soka Waterfall in terrestrial and aquatic environments. The terrestrial environment divided into settlements, tourist parks, gardens, and forests. While the aquatic environment consists of streams along the tourist park area. Data collection was carried out at 08.00-12.00 a.m for diurnal herpetofauna and at $07.30-11.00$ p.m for nocturnal herpetofauna types.

\section{Tools and Materials}

The tools used in this study were stationery, tally sheets, GPS, flashlights, timepieces, DSLR, laptops and identification book Panduan Lapang Herpetofauna (Amfibi dan Reptil) Taman Nasional Alas Purwo (Yanuerfa et al., 2012), Panduan Bergambar Amfibi di Jawa Barat (Kusrini et al., 2007) and Amfibi Jawa dan Bali (Iskandar, 1998). The material used in this study were herpetofauna species in the Sungai Mudal Park and Kembang Soka Waterfall. 


\section{Data Retrieval}

The method used in this research was VES (Visual Encounter Survey) method, works in combination with the belt-transect method. VES is a method to calculate and collect the research objects based on encounters in transect lines (Heyer et al., 1994). The belt-transect method in this study was determined based on the path that was often traversed by people in terrestrial ecosystems and along the river flow in the aquatic ecosystem. The observation limit is 5 meters to the right and left side from the trail. Because the distance between the objects still looks quite clear. Observations was carried out in 2 times, at the morning to noon are data collected for herpetofauna species whose diurnal types and at the night for herpetofauna whose nocturnal types (Putra et al., 2012). The herpetofauna identifying process used identification books Panduan Lapang Herpetofauna (Amfibi dan Reptil) Taman Nasional Alas Purwo (Yanuerfa et al., 2012), Panduan Bergambar Amfibi di Jawa Barat (Kusrini et al., 2007) and Amfibi Jawa dan Bali (Iskandar, 1998).

\section{RESULTS AND DISCUSSION}

A total of 22 Herpetofauna species has been found and identified in the Sungai Mudal Park and Kembang Soka Waterfall consists of 9 families, 5 families from the Amphibian class and 4 families from the Reptile class. The following data on the types of herpetofauna found in the area:

Table 1. Total of herpetofauna species in Sungai Mudal park and Kembang Soka waterfall.

\begin{tabular}{|c|c|c|c|}
\hline No & Family & Local Name & Scientific Name \\
\hline 1 & Bufonidae & Kodok buduk & Phryonidis aspera \\
\hline 2 & & Kodok puru & Duttaphrynus melanostictus \\
\hline 3 & Ranidae & Kongkang racun & Odorrana hosii \\
\hline 4 & & Kongkang kolam & Chalcorana chalconota \\
\hline 5 & Megophryidae & Katak Serasah & Leptobrachium hasseltii \\
\hline 6 & Rhacophoridae & Katak pohon bergaris & Polypedates leucomystax \\
\hline 7 & Dicroglossidae & Katak tegalan & Fejervarya limnocharis \\
\hline 8 & & Bangkong tuli & Limnonectes kuhlii \\
\hline 9 & Scincidae & Kadal kebun & Eutropis multifasciata \\
\hline 10 & & Kadal semak & Eutropis rugifera \\
\hline 11 & & & Sphenomorphus sanctus \\
\hline 12 & Agamidae & Bunglon hutan & Gonocephalus chamaeleontinus \\
\hline 13 & & & Gonocephalus kuhlii \\
\hline 14 & & Bunglon surai & Bronchocela jubata \\
\hline 15 & & Bunglon hijau & Bronchocela cristatella \\
\hline 16 & & Cicak terbang & Draco volans \\
\hline 17 & Gekkonidae & Cicak gula & Gehyra mutilata \\
\hline 18 & & Cicak batu & Cyrtodactylus marmoratus \\
\hline 19 & & Cicak kayu & Hemidactylus frenatus \\
\hline 20 & & Tokek rumah & Gekko gecko \\
\hline 21 & Colubridae & Ular kucing bergigi anjing & Boiga cynodon \\
\hline 22 & & Ular pucuk & Ahaetulla prasina \\
\hline
\end{tabular}
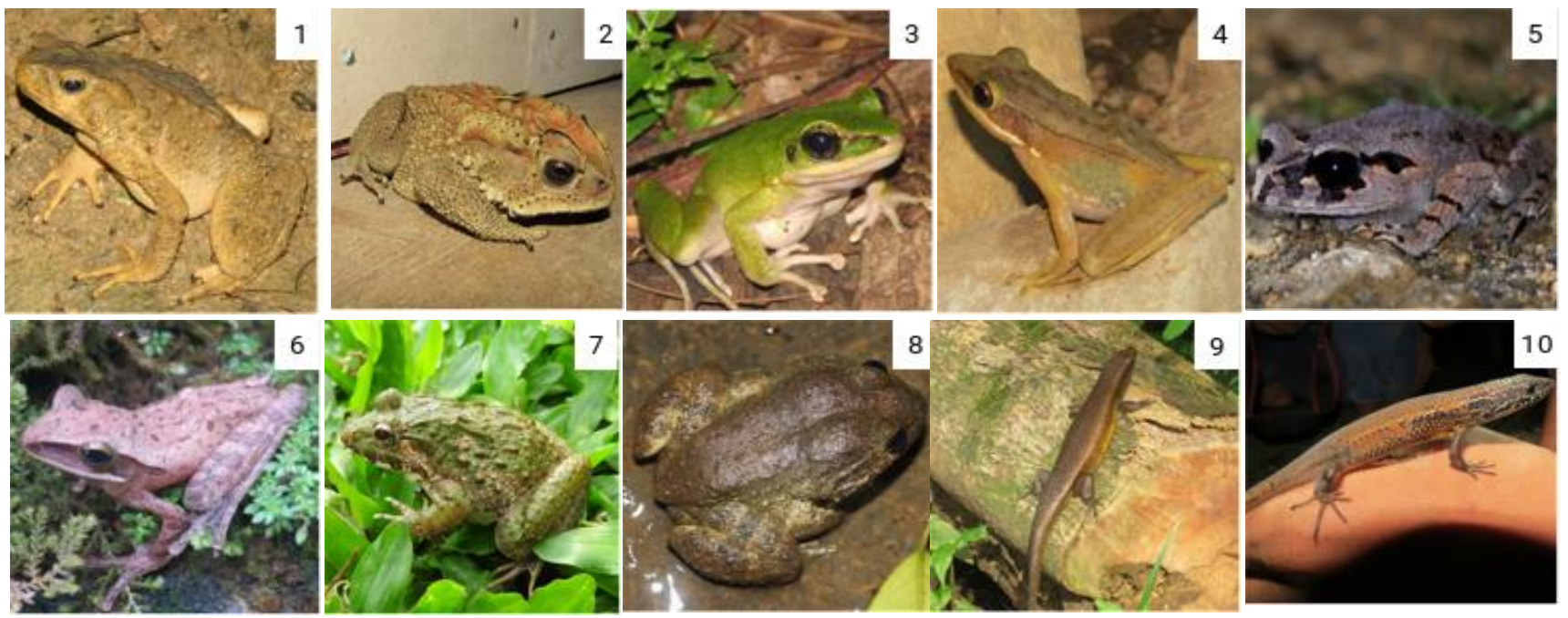

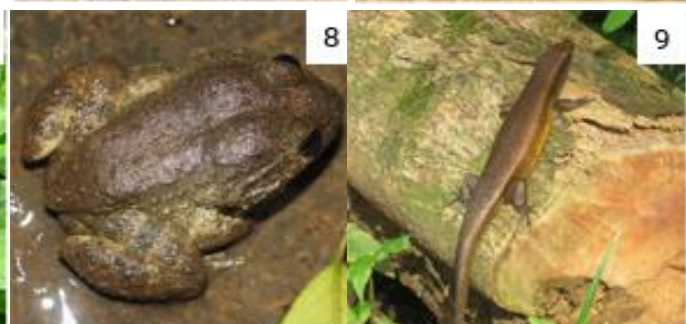

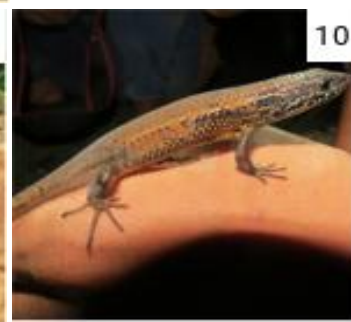



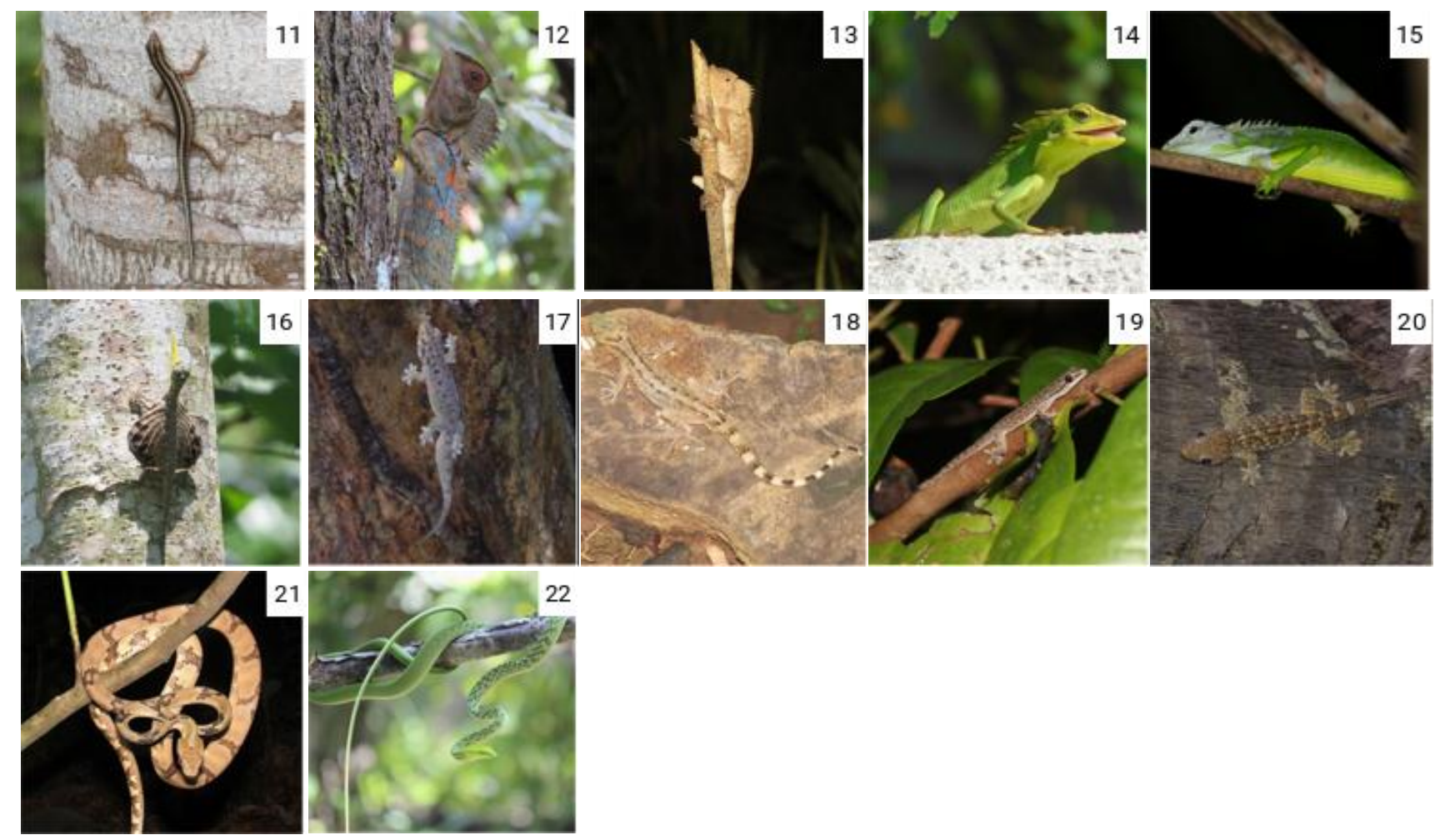

Figure 1. Herpetofauna of Sungai Mudal park and Kembang Soka waterfall.

\section{CONCLUSIONS}

The number species of herpetofauna found in the Sungai Mudal Park and Kembang Soka Waterfall were 22 species consist of 8 amphibian species and 14 reptile species.

\section{REFERENCES}

Heyer, W.R., Donnelly M.A., McDiarmid R.W., Hayek L.C and Fostre M.S. 1994. Measuring and Monitoring Biological Diversity: Standard Methods for Amphibians. Washington: Smithsonian Institution Press.

IUCN. 2013 accessed on December 25, 2017. www.iucnredlist.org
Kurniati, Hellen. 2003. Amphibians \& Reptiles of Gunung Halimun National Park, West Java, Indonesia. Cibinong: Research Center for Biology-LIPI.

Kusrini, M. D. 2007. Pedoman Penelitian dan Survey Amphibia Di Lapangan. Departemen Konservasi Sumberdaya Hutan dan Ekowisata Fakultas Kehutanan Institut Pertanian Bogor.

Putra, K., Rizaldi dan Tjong, D.H. 2012. Komunitas Anura pada Tiga Tipe Habitat Perairan di Kawasan Hutan Harapan Jambi. Jurnal Biologi. Universitas Andalas.

Qurniawan, T. F. 2013. Amfibi dan Reptil Karst Gunung Sewu Zona Batur Agung, Gunung Kidul, Daerah Istimewa Yogyakarta. Jurnal Biota. Fakultas Biologi, Universitas Gajah Mada Yogyakarta. Vol. 18, No. 2 (75-82).

Yanuarefa, M. F., Hariyanto, G., Utami, J. 2012. Panduan Lapang Herpetofauna (Amfibi dan Reptil) Taman Nasional Alas Purwo. Banyuwangi: Balai Taman Nasional Alas Purwo.

Zug, George R. 1993. Herpetology: An Introductory Biology of Amphibians and Reptiles. Academic Press. London, p: $357-$ 358. 
THIIS PAGE INTENTIONALLY LEFT BLANK 